\title{
Performance Evaluation of Network Models based on Fuzzy Queueing System ${ }^{\dagger}$
}

\author{
Jung Bok JO*1 Yasuhiro TSUJIMURA*2 Mitsuo GEN*2 \\ Genji YAMAZAKI*2
}

\section{Introduction}

Many mathematical models have been developed to solve queueing network problems. Most of these assume probability distribution for arrivals and services[8-12]. The conventional methods which are used very widely are based upon probability theory, where the probability is expressed in terms of the statistical information of its components. In some real situations, we may sometimes obtain the statistical information subjectively. Particularly, the average arrival rate and the average service rate of a queueing network model can be obtained from experts. Therefore, these data are subjective and fuzzy. In this case, we will apply to fuzzy numbers rather than crisp numbers for the arrival rate and the service rate of a queueing network model.

Fuzzy set theory is a proper means for modeling uncertainty or imprecision arising from mental phenomena. Its capability of handling uncertainty or imprecision is crucial to all the situations when the available information is not precise and the associated uncertainty can not be ignore[24]. The subjective or preference information can usually (but not always) be represented as a convex fuzzy number[25]. Thus we can use the mathematics of fuzzy calculus to handle these uncertainty and imprecise. The practical merit of fuzzy approach is that there is no need to force analyst to give a probability distribution. And fuzzy approach can get a reasonable solution suitable for all cases ranging from the pessimistic case to the optimistic case.

† ファジィ待ち行列システムによるネットワークモデルの性能 評価

曹 廷輻, 辻村 泰寞, 玄 光男, 山崎 源治

*1 Dept. of Engineering Management, Tokyo Metropolitan Institute of Technology

東京都立科学技術大学管理工学科

*2 Dept. of Industrial and Systems Engineering, Ashikaga Institute of Technology

足利工業大学経営工学科
The problems in modeling with fuzzy queueing system have been analyzed by Prade[1], and $\mathrm{Li}$ and Lee[5] through the use of the extension principle. Stanford[21] presented the existence of a unique limiting set for a finite state Markov chain with fuzzy transition probabilities. Buckley[2] considers elementary queueing systems which have with multiple parallel servers with finite or infinite system capacity and calling source, whose arrivals and services are restricted by arbitrary possibility distributions. Negi and Lee's contribution[4] was shown that their approach can utilize the advantages of both the fuzzy and probability approaches to make the model more realistic and less restrictive. Their approach for $F / F / 1$ system is a single value simulation of a fuzzy variable by the use of two random variables. Recently Yoshida[22] constructs a Markov fuzzy process, which represents the transitions of grades of fuzzy sets, with a transition possibility measure and a general state space.

In this paper, we will present the fuzzification of queueing system and the performance evaluation of network models based on the fuzzy set theory. Also, we will show that this performance evaluation is more flexible and realistic than crisp one of conventional method through some numerical examples.

\section{Preliminaries}

There are various types of fuzzy number to express vagueness[23], the triangular fuzzy number(TFN) among these types is appropriate to express the average arrival rate and the average service rate of fuzzy queueing network models because a TFN is represented by a triplet, i.e., a minimum value, a modal value and a maximum value. Therefore, we use fuzzy numbers which are characterized by $\alpha$-cuts and TFNs. The reason for using these characterizations is the simplicity and flexibility for the intervals of confidence and the 
triangular shapes. It is well known in fuzzy approach that the interval of confidence associated with monotonic functions can be very convenient.

The TFNs are used extensively in modeling of systems because fuzzy numbers of this type are very simple to treat. In this model, to use a trapezoidal fuzzy number is seldom appropriate to express the average arrival rate and the average service rate of fuzzy queueing network models because the modal value of it has a width.

Let us introduce the notation needed in the rest of the paper. All our fuzzy numbers will be triangular shaped. We will place a tilde over a capital letter if it represents a TFN, so $\widetilde{A}, \widetilde{B}, \widetilde{C}, \widetilde{X}, \widetilde{N}, \widetilde{N}$ $Q$ are all TFNs. Let $\widetilde{A}$ be a TFN with membership function $\mu_{\tilde{A}}(x)$. We represent an interval of confidence of TFN $\widetilde{A}$ for all $\alpha$-cut level, that is, $A(\alpha)=\left[\mathrm{a}_{L}^{(\alpha)}, \mathrm{a}_{R}^{(\alpha)}\right]$ for $\alpha \in[0,1]$. If $\alpha=1, a_{L}^{(\alpha)}$ is equal to $a_{R}^{(\alpha)}$. And the TFNs $\widetilde{A}$ and $\widetilde{P}_{n}$ are represented by triplet $\left(a_{1}, a_{2}, a_{3}\right)$ and $\left(p_{n, 1}, p_{n, 2}\right.$, $\left.p_{n, 3}\right)$ respectively. The membership function, $\mu_{\widetilde{A}}(x)$ is partially specified by $\left(a_{1}, a_{2}, a_{3}\right)$ where:

(1) $a_{1}<a_{2}<a_{3}$;

(2) $\mu_{\widetilde{A}}(x)=0$ outside $\left(a_{1}, a_{3}\right)$ and equals one at $a_{2} ;$

(3) $\mu_{\widetilde{A}}(x)$ is continuous and monotonically increasing between 0 and 1 on $\left[a_{1}, a_{2}\right]$;

(4) $\mu_{\tilde{A}}(x)$ is continuous and monotonically decreasing from one to zero on $\left[a_{2}, a_{3}\right]$.

For any TFN $\widetilde{A}$, we can write as follows :

(1) $\tilde{A} \geqq c$ if $a_{1} \geqq c$;

(2) $\tilde{A}>c$ if $a_{1}>c$;

(3) $\widetilde{A} \leqq c$ if $a_{3} \leqq c$;

(4) $\tilde{A}<c$ if $a_{3}<c$,

where $c$ is a crisp real number. The support of $\widetilde{A}$ is $\left(a_{1}, a_{3}\right)$. Comparisons of two TFNs are assumed to be made by Kaufmann and Gupta [23] methodology using linear ordering of fuzzy numbers. In this paper, addition, subtraction, multiplication and division of fuzzy numbers are used to the intervals of confidence for $\alpha$-cut level.

Definition 1 : For TFNs $\widetilde{A_{1}}=\left(a_{1,1}, a_{1,2}, a_{1,3}\right)$, $\widetilde{A_{2}}=\left(a_{2,1}, a_{2,2}, a_{2,{ }_{3}}\right), \ldots, \widetilde{A}_{n}=\left(a_{n}, 1, a_{n, 2}\right.$, $\left.a_{n, 3}\right)$, we define an average TFN $\widetilde{A}$ as follows [26]:

$$
\begin{aligned}
& \widetilde{A}=\left(\frac{a_{1,1}+\cdots+a_{n, 1}}{n}, \quad \frac{a_{1,2}+\cdots+a_{n, 2}}{n},\right. \\
& \left.\frac{a_{1,3}+\cdots+a_{n, 3}}{n}\right) \text {. }
\end{aligned}
$$

Dubois and Prade[3] and Zimmermann[7] have defined the fuzzifying function and its integration over a crisp interval as follows:

Definition 2 : Let $X$ and $Y$ be universes and $P(Y)$ be the set of all fuzzy sets in $Y$ (power set).

$\widetilde{f}: X \rightarrow \widetilde{P}(Y)$ is a mapping.

$\widetilde{f}$ is a fuzzified function, iff

$$
\mu_{\tilde{f}(x)}(y)=\mu_{\widetilde{R}}(x, y), \quad \forall(x, y) \in X \times Y,
$$

where $\mu_{\tilde{R}}(x, y)$ is the membership function of a fuzzy relation[7].

Definition 3 : Let $\widetilde{f}(x)$ be a fuzzified function from $[a, b] \subseteq R$ to $R$, such that, $\widetilde{f}(x), \forall x \in[a$, $b]$ is a fuzzy number. Let $\alpha$-level curves $f_{\bar{\alpha}}^{-}(x)$ and $f_{\alpha}^{+}(x)$ be the curves on $[a, b]$ which satisfy the following estimates for any $x \in[a, b]$ :

$$
\begin{aligned}
& \mu_{\tilde{f}(x)}\left(f_{\alpha}^{-}(x)\right)=\mu_{\tilde{f}(x)}\left(f_{\alpha}^{+}(x)\right)=\alpha, \\
& f_{\bar{\alpha}}^{-}(x) \leqq f_{\alpha}^{+}(x) .
\end{aligned}
$$

The integral of $\widetilde{f}(x)$ over $[a, b]$ is then defined to be the fuzzy set as follows[7] :

$$
\begin{aligned}
\int_{a}^{b} \tilde{f}(x) d x \\
\quad=\left\{\left(\left[\int_{a}^{b} f_{\bar{\alpha}}^{-}(x) d x, \int_{a}^{b} f_{\alpha}^{+}(x) d x\right], \alpha\right)\right\} .
\end{aligned}
$$

Sanchez [13] represented solutions of fuzzy equations using extended operations. Buckley and $\mathrm{Qu}[14]$ presented necessary and sufficient conditions for $\widetilde{A}+\widetilde{X}=C$ and $\widetilde{A} \cdot \widetilde{X}=\widetilde{C}$ to have solutions for $\widetilde{X}$, when $\widetilde{A}$ and $\widetilde{C}$ are arbitrary fuzzy subsets of the real numbers.

Theorem 1 : The fuzzy equation $\widetilde{A}+\widetilde{X}=\widetilde{C}$ has a solution $\widetilde{X}$ iff $c_{1}-a_{1}<c_{2}-a_{2}<c_{3}-a_{3}$. If there is a solution, then $\widetilde{X}$ is the TFN $\left(c_{1}-a_{1}, c_{2}-a_{2}, c_{3}-\right.$ $\left.a_{3}\right)$.

Proof. Taking $\alpha$-cuts we obtain $a_{L}^{(\alpha)}+x_{L}^{(\alpha)}=c_{L}^{(\alpha)}$ and $a_{R}^{(\alpha)}+x_{R}^{(\alpha)}=c_{R}^{(\alpha)}$. Then $x_{1}<x_{2}<x_{3}$ and $1 /\left(x_{2}-x_{1}\right)>0$, $1 /\left(x_{2}-x_{3}\right)<0$ iff $c_{1}-a_{1}<c_{2}-a_{2}<c_{3}-a_{3}$.

Definition 4 : Using Theorem 1 , in order to obtain a solution $\widetilde{X}$ for a fuzzy equation $\widetilde{A}+\widetilde{X}=\widetilde{C}$, we define the operator $\ominus$ as follows :

$$
\begin{aligned}
& \forall \alpha \in[0,1] \\
& \quad \widetilde{C} \odot \widetilde{A}=\left(c_{1}-a_{1}, \quad c_{2}-a_{2}, c_{3}-a_{3}\right) .
\end{aligned}
$$

Theorem 2: We assume that $\widetilde{A}>0$ and $\widetilde{C} \geqq 0$. 
Then there is a solution $\widetilde{X}$ of the fuzzy equation $\widetilde{A} \cdot \widetilde{X}=\widetilde{C}$ iff $a_{1} c_{2}>a_{2} c_{1}$ and $a_{3} c_{2}<a_{2} c_{3}$ when $\tilde{A}>0$, $\widetilde{C} \geqq 0$

Proof. Taking $\alpha^{\text {-cuts }}$ we obtain $x_{L}^{(\alpha)}=\mathrm{c}_{L}^{(\alpha)} / \mathrm{a}_{L}^{(\alpha)}$, $\mathrm{x}_{R}^{(\alpha)}=\mathrm{c}_{R}^{(\alpha)} / \mathrm{a}_{R}^{(\alpha)}$ when $\tilde{A}>0, \quad \widetilde{C} \geqq 0$. We obtain $1 /$ $\left(x_{2}-x_{1}\right)>0$ and $1 /\left(x_{2}-x_{3}\right)<0$, iff the conditions stated above hold.

Definition 5 : We assume that $\widetilde{A}>0$ and $\widetilde{C} \geqq 0$. Using Theorem 2 , in order to obtain a solution $\widetilde{X}$ for a fuzzy equation $\tilde{A} \cdot \widetilde{X}=C$, we define the operator $\odot$ as follows :

$$
\begin{aligned}
& \forall \alpha \in[0,1] \\
& \quad \widetilde{C} \odot \widetilde{A}=\left(\frac{c_{1}}{a_{1}}, \frac{c_{2}}{a_{2}}, \frac{c_{3}}{a_{3}}\right),
\end{aligned}
$$

iff $a_{1} c_{2}>a_{2} c_{1}$ and $a_{3} c_{2}<a_{2} c_{3}$

$$
\text { when } \widetilde{A}>0 \text { and } \widetilde{C} \geq 0 \text {. }
$$

Theorem $3:$ We assume that $\widetilde{A}>0, \widetilde{C} \geqq 0$. Then there is a solution $\tilde{X}$ of the fuzzy equation $\tilde{X} \odot$ $\widetilde{A}=\widetilde{C}$ iff $c_{1} a_{3}<c_{2} a_{2}<c_{3} a_{1}$ when $\widetilde{A}>0$ and $\widetilde{C} \geqq 0$.

Proof. Taking $\alpha$-cuts we obtain $x_{L}^{(\alpha)}=c_{L}^{(\alpha)} a_{R}^{(\alpha)}, x_{R}^{(\alpha)}=$ $c_{R}^{(\alpha)} a_{L}^{(\alpha)}$ when $\widetilde{A}>0, \quad \widetilde{C} \geqq 0$. We obtain $1 /\left(x_{2}-x_{1}\right)>0$ and $1 /\left(x_{2}-x_{3}\right)<0$, iff the condition stated above hold.

Theorem 4: We assume that two TFNs, $\widetilde{A}>0$ and $\widetilde{C} \geqq 0$. When we attempt to obtain a solution $\widetilde{X}$ for a fuzzy equation $\widetilde{X} \odot \widetilde{A}=\widetilde{C}$ using Theorem 3 , the solution $\tilde{X}$ dose not become a TFN. Therefore, we will approximate the solution by a TFN. Then we define the operator $\odot$ as following :

$$
\begin{aligned}
& \widetilde{X}=\widetilde{A} \odot=\left(\begin{array}{ll}
a_{3} c_{1}, & a_{2} c_{2}, \\
a_{1} c_{3}
\end{array}\right), \\
& \text { iff } a_{3} c_{1}<a_{2} c_{2}<a_{1} c_{3}, \text { when } \widetilde{A}>0, \quad \widetilde{C} \geq 0 .
\end{aligned}
$$

And we also assume that $0<\widetilde{A}<1$ and $\widetilde{C} \geqq 0$. Then there is a solution $\widetilde{X}$ of the fuzzy equation $\tilde{X}$ $\odot(1-\widetilde{A})=\widetilde{C}$ iff $\left(1-a_{1}\right) c_{1}<\left(1-a_{2}\right) c_{2}<\left(1-a_{3}\right) c_{3}$ when $\widetilde{A}>0$ and $\widetilde{C} \geqq 0$.

Proof. Taking $\alpha$-cuts we obtain $x_{L}^{(\alpha)}=\left(1-a_{L}^{(\alpha)}\right) c_{L}^{(\alpha)}$, $x_{R}^{(\alpha)}=\left(1-a_{R}^{(\alpha)}\right) c_{R}^{(\alpha)}(\alpha)$ when $0<\widetilde{A}<1, C \geqq 0$. We can obtain $1 /\left(x_{2}-x_{1}\right)>0$ and $1 /\left(x_{2}-x_{3}\right)<0$, iff the condition stated above is held. By Theorem 4 , we can obtain a fuzzy number solution $\widetilde{X}$ of the fuzzy equation $\widetilde{X} \odot(1-\widetilde{A})=\widetilde{C}$ and approximate $\alpha$-cut solution by a approximate TFN, that is,

$$
\begin{aligned}
& \widetilde{X} \fallingdotseq(1-\widetilde{A}) \odot \widetilde{C} \\
& \text { iff } \quad\left(1-a_{1}\right) c_{1}<\left(1-a_{2}\right) c_{2}<\left(1-a_{3}\right) c_{3} \\
& \quad \text { when } \widetilde{A}>0 \text { and } \widetilde{C} \geq 0 .
\end{aligned}
$$

The following notations are used throughout this paper:
$\widetilde{N}(t)$ : number of customers in the system at time $t$ $\widetilde{A}(t)$ : number of customers who arrived in the interval $[0, t]$

$\widetilde{N}$ : average number of customers in the system

$\widetilde{W}$ : average waiting time in the system

$\tilde{N}_{Q}:$ average number of customers in queue

$\widetilde{W}_{Q}$ : average waiting time in queue

$\lambda$ : average arrival rate of customers

$\tilde{\mu}$ : average service rate of customers

$\widetilde{P}_{n}$ : probability of $\mathrm{n}$ customers in the system.

Definition 6 : Let $\bar{P}_{n}$ be the associate value of a TFN $\widetilde{P}_{n}=\left(p_{n, 1}, p_{n, 2}, p_{n},{ }_{3}\right)$, where $p_{n, 1} \geqq 0$, $p_{n, 3} \leqq 1$. We define a fuzzy probability as a TFN $\widetilde{P}_{n}$ of which associate value $\bar{P}_{n}$ is characterized as folows :

$$
\sum_{n=0}^{\infty} \bar{P}_{n}=1 .
$$

We use the mode $p_{n, 2}$ as the associate value $\bar{P}_{n}$. The membership of the fuzzy probability[27] $\widetilde{P}_{n}$ is shown in Fig.1.

Now, we introduce fuzzy set theory into the Little's law[15-20]. The fuzzy number of customers in the system observed up to time $t$ is as follows :

$$
\widetilde{N}_{t}=\frac{1}{t} \int_{0}^{t} \tilde{N}(\tau) d \tau,
$$

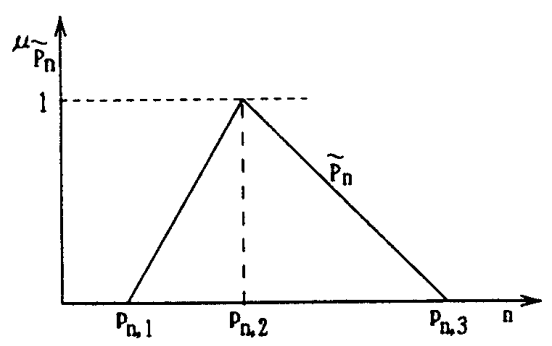

Fig.1 Fuzzy probability

where a fuzzified function $\widetilde{N}(\tau)$ and a integration of fuzzified function are defined by Definition 2, 3, respectively. Of course, $\widetilde{N}_{t}$ depends on $t$, but $\widetilde{N}_{t}$ tends to a steady-state $\widetilde{N}$ according to increment of $t$, that is,

$$
\widetilde{N}=\lim _{t \rightarrow \infty} \widetilde{N}_{t}
$$

The fuzzy arrival rate over the interval $[0, t]$ is as follows:

$$
\tilde{\lambda_{t}}=\frac{\tilde{A}(t)}{t} .
$$

For the steady-state, it is defined as 


$$
\tilde{\lambda}=\lim _{t \rightarrow \infty} \tilde{\lambda_{t}},
$$

with assuming that the limit exist. The fuzzy average time of the customer delay up to time $t$ is similarly defined as

$$
\widetilde{W}_{t} \doteqdot \frac{1}{\widetilde{A}(t)} \int_{0}^{t} \widetilde{N}(\tau) d \tau,
$$

that is, the fuzzy average time spent in the system. per a customer up to time $t$. The steady-state fuzzy average time of the customer delay is defined as

$$
\widetilde{W}=\lim _{t \rightarrow \infty} \widetilde{W}_{t},
$$

with assuming that the limit exists. Therefore, we have

$$
\widetilde{W} \fallingdotseq \frac{\widetilde{N}}{\widetilde{\lambda}}
$$

Eq. (13) is represented using $\alpha$-cut level, as follows :

$$
\begin{aligned}
& \forall \alpha \in[0,1], \\
& W(\alpha)=\left[\frac{N_{L}^{(\alpha)}}{\lambda_{R}^{(\alpha)}}, \frac{N_{R}^{(\alpha)}}{\lambda_{L}^{(\alpha)}}\right] .
\end{aligned}
$$

By deconvolution of eq. (14) we can compute the $\widetilde{N}$ with interval of confidence as follows:

$$
\begin{aligned}
& \forall \alpha \in[0,1], \\
& N(\alpha)=\left[\lambda_{R}^{(\alpha)} W_{L}^{(\alpha)}, \lambda_{L}^{(\alpha)} W_{R}^{(\alpha)}\right] .
\end{aligned}
$$

Similar formulas exist for $\widetilde{N}_{Q}$ and $W_{Q}$, that is

$$
\widetilde{W}_{Q} \fallingdotseq \frac{\widetilde{N}_{Q}}{\tilde{\lambda}} \text {. }
$$

And we have

$$
\begin{aligned}
& \forall \alpha \in[0,1], \\
& N_{Q}(\alpha)=\left[\lambda_{R}^{(\alpha)} W_{Q L}^{(\alpha)}, \lambda_{L}^{(\alpha)} W_{Q R}^{(\alpha)}\right] .
\end{aligned}
$$

If the number of customers in the system, $N$, is not fuzzy number but crisp number eqs. (7), (8), (11), (13), and (14) can be as follows:

$$
\begin{aligned}
& N_{t}=\frac{1}{t} \int_{0}^{t} N(\tau) d \tau, \\
& N=\lim _{t \rightarrow \infty} N_{t} . \\
& \widetilde{W}_{t}=\frac{1}{\widetilde{A}(t)} \int_{0}^{t} N(\tau) d \tau, \\
& \widetilde{W}=\frac{N}{\widetilde{\lambda}}, \\
& \forall \alpha \in[0,1], \\
& W(\alpha)=\left[W_{L}^{(\alpha)}, W_{R}^{(\alpha)}\right]=\left[\frac{N}{\lambda_{L}^{(\alpha)}}, \frac{N}{\lambda_{R}^{(\alpha)}}\right] .
\end{aligned}
$$

\section{The Fuzzy M/M/1 Queueing System}

The fuzzy $M / M / 1$ queueing system consists of a single queueing station with a single server. Customers arrive according to a Poisson process with fuzzy rate $\tilde{\lambda}$, and the fuzzy probability distribution of the service time is exponential with fuzzy mean $1 / \tilde{\mu}$ second. From one among of the properties of the Poisson process with fuzzy parameter $\tilde{\lambda}[5]$, we can get:

For every $t \geqq 0$ and $\delta \geqq 0$,

$$
\begin{aligned}
& \widetilde{P}\{N(t+\delta)-N(t)=0\}=\sum_{n=0}^{\infty} \widetilde{P}_{n}-\tilde{\lambda} \delta+o(\delta) \\
& \widetilde{P}\{N(t+\delta)-N(t)=1\}=\tilde{\lambda} \delta+o(\delta) \\
& \widetilde{P}\{N(t+\delta)-N(t) \geq 2\}=o(\delta)
\end{aligned}
$$

where we generically denoted by $o(\delta)$ a function of $\delta$ such that

$$
\lim _{\delta \rightarrow 0} \frac{o(\delta)}{\delta}=0
$$

\subsection{Fuzzy Markov chain formulation}

We could analyze the process $\widetilde{N}(t)$ in terms of the discrete-time fuzzy Markov chains. Let us focus attention at the times

$$
0, \delta, 2 \delta, \ldots, k \delta, \ldots
$$

where $\delta$ is a small positive number. We denote that $N_{k}$ is the number of customers in the system at time $k \delta$. Let $\widetilde{P}_{i j}$ denotes the corresponding fuzzy transition probabilities[21],

$$
\widetilde{P}_{i j}=\widetilde{P}\left\{N_{k+1}=j \mid N_{k}=i\right\}, 1 \leq i, j \leq n .
$$

By using eqs. (18) through (20), one can show that

$$
\begin{aligned}
& \widetilde{P}_{00}=\sum_{i=0, j=0}^{\infty} \widetilde{P}_{i j}-\tilde{\lambda} \delta+o(\delta) \\
& \widetilde{P}_{i i}=\sum_{i=0, j=0}^{\infty} \widetilde{P}_{i j}-\tilde{\lambda} \delta-\tilde{\mu} \delta+o(\delta) \quad i \geq 1 \\
& \widetilde{P}_{i i+1}=\tilde{\lambda} \delta+o(\delta) \quad i \geq 0 \\
& \widetilde{P}_{i i-1}=\tilde{\mu} \delta+o(\delta) \quad i \geq 1 \\
& \widetilde{P}_{i j}=o(\delta) \quad i \text { and } j \neq i, \quad i+1, \quad i-1 .
\end{aligned}
$$

The state transition diagram for the fuzzy Markov chain $\left\{N_{k}\right\}$ is shown in Fig. 2, where we have omitted the terms $o(\delta)$. 


\subsection{Derivation of the stationary distribution}

Consider now the steady-state fuzzy probabilities

$$
\widetilde{P}_{n}=\lim _{t \rightarrow \infty} \widetilde{P}\{N(t)=n\} .
$$

Note that during any time interval, the total number of transitions from state $n$ to $n+1$ must differ from the total number of transitions from $n+1$ to $n$ by at most 1 . Thus asymptotically, the frequency of transitions from $n$ to $n+1$ is equal to the frequency of transitions from $n+1$ to $n$. Equivalently, the fuzzy probability that the system is in state $n$ and makes a transition to $n+1$ in the next transition interval is the same as the fuzzy probability that the system is in state $n+1$ and makes a transition to $n$, i.e.,

$$
\widetilde{P}_{n} \tilde{\lambda} \delta+o(\delta)=\widetilde{P}_{n+1} \tilde{\mu} \delta+o(\delta) .
$$

By taking the limit in this equation as $\delta \rightarrow 0$, we obtain

$$
\widetilde{P}_{n} \lambda=\widetilde{P}_{n+1} \tilde{\mu} .
$$

Eq. (27) can be also written using Theorem 2 as

$$
\begin{aligned}
& \widetilde{P}_{n+1}=\tilde{\rho} \widetilde{P}_{n .} \\
& \text { iff } \mu_{1} P_{n},{ }_{2} \lambda_{2}>\mu_{2} P_{n},{ }_{1} \lambda_{1} \\
& \text { and } \mu_{3} P_{n},{ }_{2} \lambda_{2}<\mu_{2} P_{n},{ }_{3} \lambda_{3},
\end{aligned}
$$

where

$$
\tilde{\rho}=\tilde{\lambda} \odot \tilde{\mu} .
$$

we assume that $\lambda_{1} \mu_{2}<\lambda_{2} \mu_{1}$ and $\lambda_{2} \mu_{3}<\lambda_{3} \mu_{2}$, therefore $\tilde{\rho}$ is a TFN. It follows that

$$
\widetilde{P} \fallingdotseq \tilde{\rho}^{n} \widetilde{P}_{0}
$$

If $\tilde{\rho}<1$, the fuzzy probabilities $\widetilde{P}_{n}$ are all positive, so

$$
\sum_{n=0}^{\infty} \widetilde{P}_{n}=\sum_{n=0}^{\infty} \widetilde{\rho}^{n} \widetilde{P}_{0} \fallingdotseq \frac{\widetilde{P}_{0}}{1-\tilde{\rho}} .
$$

Combining eqs. (30) and (31), we finally obtain

$$
\widetilde{\mathrm{P}}_{n}=\tilde{\rho}^{n}\left\{(1-\tilde{\rho}) \odot \sum_{\mathrm{n}=0}^{\infty} \widetilde{\mathrm{P}}_{n}\right\}, \text { ǹ } 1,2,3, \cdots
$$

We can now calculate the fuzzy average number of customers in the system in steady-state:

$$
\begin{aligned}
\widetilde{N} \fallingdotseq \frac{\sum_{n=0}^{\infty} n \widetilde{P}_{n}}{\sum_{n=0}^{\infty} \widetilde{P}_{n}}=\frac{\sum_{n=0}^{\infty} n \tilde{\rho}^{n}\left\{(1-\tilde{\rho}) \odot \sum_{n=0}^{\infty} \widetilde{P}_{n}\right\}}{\sum_{n=0}^{\infty} \widetilde{P}_{n}} \\
=\frac{\tilde{\rho} \sum_{n=0}^{\infty} \widetilde{P}_{n}}{(1-\tilde{\rho}) \sum_{n=0}^{\infty} \widetilde{P}_{n}}
\end{aligned}
$$

The fuzzy average delay per customer is given by the fuzzy Little's law,

$$
\widetilde{W}=\frac{\widetilde{N}}{\tilde{\lambda}} \fallingdotseq \frac{\tilde{\rho} \sum_{n=0}^{\infty} \widetilde{P}_{n}}{\tilde{\lambda}(1-\tilde{\rho}) \sum_{n=0}^{\infty} \widetilde{P}_{n}} .
$$

If eq. (34) is represented by $\alpha$-cut level, we have

$$
\begin{aligned}
& \forall \alpha \in[0,1], \\
& W(\alpha)=\left[\frac{\rho_{\alpha}^{(\alpha)} c_{L}^{(\alpha)}}{\lambda_{R}^{(\alpha)} c_{R}^{(\alpha)}\left(1-\rho_{L}^{(\alpha)}\right)}, \frac{\rho_{R}^{(\alpha)} c_{R}^{(\alpha)}}{\lambda_{L}^{(\alpha)} c_{L}^{(\alpha)}\left(1-\rho_{R}^{(\alpha)}\right)}\right] .
\end{aligned}
$$

The fuzzy average waiting time in queue $\widetilde{W}_{Q}$, is the fuzzy average delay $\widetilde{W}$ less the fuzzy average service time $1 / \tilde{\mu}$, so

$$
\widetilde{W}_{Q} \fallingdotseq \frac{\tilde{\rho} \sum_{n=0}^{\infty} \widetilde{P}_{n}}{\tilde{\lambda}(1-\tilde{\rho}) \sum_{n=0}^{\infty} \widetilde{P}_{n}}-\frac{1}{\tilde{\mu}} .
$$

In general, the approximation becomes worse according to iteration of the multiplication and the division of TFNs. That is, these operations for TFNs in a computational process may give rise to an error which may then be amplified in subsequent operations. It is important to note that approximation is never affected by a triplet, i.e., $a_{1}, a_{2}$ and $a_{3}$.

\section{Fuzzy Queueing Network Models}

\subsection{Fuzzy Open Central Server Model}

One of the key performance concepts used in studying a computer s:'stem is the bottleneck device or server. The bottleneck of a system is the first server to saturate as the load on the system is increased. We can identify the bottleneck of the system if we know the service demands $\widetilde{D}_{k}$, for $k=$

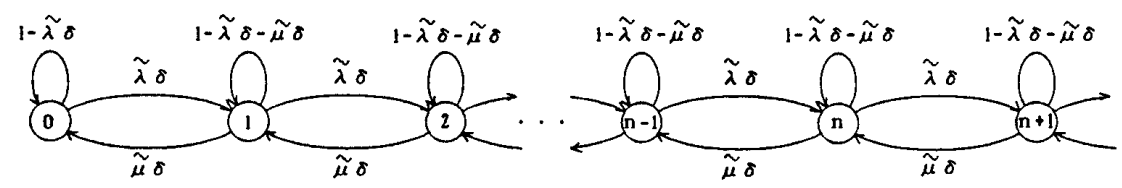

Fig.2 Discrete-time Markov chain with fuzzy transition probabilities for the $M / M / 1$ system. 
$1,2, \ldots, K$. The bottleneck device is device $j$ where $j$ is the integer for which $\widetilde{D_{j}}=\widetilde{D}_{\max }$, where

$$
\widetilde{D}_{\max }=\max \left\{\widetilde{D}_{1}, \widetilde{D}_{2}, \cdots, \widetilde{D}_{K}\right\} .
$$

Now, for an application of the proposed fuzzy queueing model, we consider that the open central server system, shown in Fig. 3. The central server is, of course, the CPU. Lavenberg and Sauer in Lavenberg[12] use the central server queueing model to study memory management of a multiprogramming system. They were trying to optimize the performance of operating system. The open central server model can be used to model a system, such as a transaction processing system in which the system is not limited by the multiprogramming level. As shown in Fig. 3, there are $K-1 \mathrm{I} / \mathrm{O}$ devices, each with its own queue, and each exponentially distributed with average service rate $\tilde{\mu}_{k}(k=2,3, \ldots, K)$.

The CPU was assumed to have an exponential distribution. The queue discipline is assumed to be first come first serve (FCFS) for the I/O devices. Upon completion of a CPU service, a transaction exits the system with fuzzy probability $\widetilde{B}_{1}$ or enters service at I/O device $k$ with fuzzy probability $\widetilde{B}_{k}$ $(k=2,3, \ldots, K)$. Upon completion of an $\mathrm{I} / \mathrm{O}$ service, the transaction returns to the CPU queue for another cycle. An incoming arrow leading to the CPU queue is added to indicate the arriving traffic with average rate $\tilde{\lambda}$. The arrival pattern is assumed to have an exponential interarrival time with fuzzy parameter. We assume the system is not overload, so the throughput is also $\tilde{\lambda}$. Therefore, Jackson's theorem [6] can be applied to the system as stated in the following algorithm :

Algorithm 1 (Lavenberg's algorithm)

Consider the open central server system described above. Suppose we are given the average arrival rate $\tilde{\lambda}$, the average service time at each

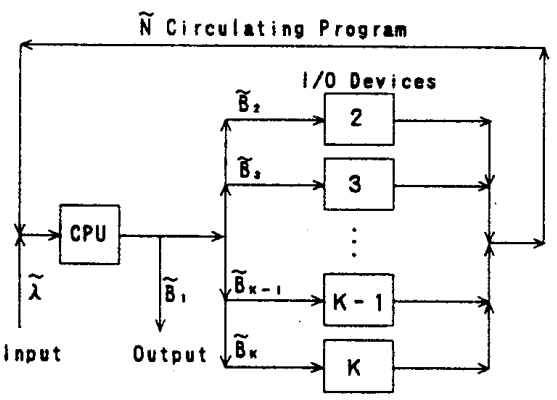

Fig 3. Open central server system. device, $\widetilde{S}_{k}(k=2,3, \ldots, K)$, and branching probabilities $\widetilde{B}_{k}(k=2,3, \ldots, K)$. The service demand, $\widetilde{D}_{k}$, is the total amount of service that a customer needs at the $k$-th device. $\widetilde{V}_{k}$ and $\tilde{\rho}_{k}$ are visit ratio and utilization at the $k$-th device, respectively. And $N_{k}$ is the average number of transactions at the $k-t h$ device. Then we use Jackson's theorem to calculate the performance measures of the system as follows:

Step 1 [Calculate the demands, $\widetilde{D}_{k}$ ]

If the demands are not known, use the Algorithm 2 to calculate

$\widetilde{D}_{k}, \quad k=1,2, \cdots, K$.

Step 2 [Calculate device performance]

For $k=1,2, \ldots, K$, calculate $\tilde{\rho}_{k} \fallingdotseq \tilde{\lambda} \cdot \widetilde{D}_{k}$,

$$
\widetilde{N}_{k} \fallingdotseq \frac{\widetilde{\rho}_{k} \sum_{n=0}^{\infty} \widetilde{P}_{n}}{\left(1-\tilde{\rho}_{k}\right) \sum_{n=0}^{\infty} \widetilde{P}_{n}} \text { and } \widetilde{W}_{k} \fallingdotseq \frac{\tilde{\lambda} \widetilde{D}_{k} \sum_{n=0}^{\infty} \widetilde{P}_{n}}{\tilde{\lambda}\left(1-\tilde{\rho}_{k}\right) \sum_{n=0}^{\infty} \widetilde{P}_{n}} \text {. }
$$

Step 3 [Compute system performance measures]

Set average response time (average time in system) to

$$
\widetilde{W}=\sum_{k=1}^{K} \widetilde{W}_{k}
$$

Set average number of transaction in the sys. tem to

$$
\begin{aligned}
& \forall \alpha \in[0,1], \\
& N(\alpha)=\left[\lambda_{R}^{(\alpha)} W_{L}^{(\alpha)}, \lambda_{L}^{(\alpha)} W_{R}^{(\alpha)}\right] .
\end{aligned}
$$

The bottleneck device is device $j$, where $j$ is the integer for which $\widetilde{D}_{j}=\widetilde{D}_{\max }$, where

$$
\widetilde{D}_{\max }=\max \left\{\widetilde{D}_{1}, \widetilde{D}_{2}, \cdots, \widetilde{D}_{K}\right\} \text {. }
$$

The maximum possible throughput is given by

$$
\tilde{\lambda_{\max }} \fallingdotseq \frac{1}{\widetilde{D}_{\max }} \text {. }
$$

\section{Algorithm 2}

Consider the open central server system of Fig. 3 . This algorithm is constructed with the parameters needed to use Labenverg's algorithm.

Step 1 Set the visit ratio $\widetilde{V}_{1}$ for the CPU to

$$
\widetilde{V}_{1} \doteqdot \frac{1}{\widetilde{B}_{1}} .
$$

Step 2 For $k=2,3, \ldots, K$ calculate

$$
\widetilde{V}_{k} \fallingdotseq \widetilde{B}_{k} \cdot \widetilde{V}_{1} \text {. }
$$


Step 3 [Calculate the demands, $\left.\widetilde{D_{k}}\right]$

Set

$$
\widetilde{D}_{k} \fallingdotseq \widetilde{V}_{k} \cdot \widetilde{S}_{k}, \quad k=1,2, \cdots, K .
$$

\subsection{Fuzzy BCMP Queueing Network Model}

In their classic paper Baskett, Chandy, Muntz, and Palacios[11] generalized the Jackson queueing network to allow different classes of customers, each with different service requirements, as well as service time distributions other than exponential. They also allow open, closed, mixed networks of queues. Finally, they allow customers to change classes after completing service at a service center before going to another service center. There are four types of service centers, each with a different queueing discipline. There are four types of service centers are :

Type 1: The queue discipline is first come first serve, and each customer has the same exponential service requirement. The service rate can be load dependent with $\tilde{\mu}(j)$ representing the service rate when there are $j$ customers at the center.

Type $2:$ The queue discipline is processor sharing. That is, each of $n$ customers receives $1 / n$ of the service effort. Each class of customer may have a distinct service time distribution.

Type $3:$ In this service discipline there is one server for each customer. Each class of customer may have a distinct service time distribution. We will sometimes describe a Type 3 service center as a delay center.

Type 4: The queue discipline is last come first serve preemptive repeat with a single server. Each class of customer may have a distinct service time distribution.

In our paper of fuzzy BCMP queueing network model, we will consider important special cases. For example, we do not allow customer class switching.

The closed BCMP model for one class is shown in Fig. 4. The $N$ terminals are Type 3 servers (delay centers), the CPU can be considered either a Type 1(exponential) or Type 2 (processorsharing) server and the $\mathrm{I} / \mathrm{O}$ devices are all Type 1 servers. The main memory of this system is not modeled. That is, there is no queue for requests to enter main computer memory. This means that no limit is imposed on the number of requests that can, simultaneously, reside in the central computer sys- tem. The mean value analysis (MVA) algorithm for calculating the performance measures of the computer system of Fig. 4.

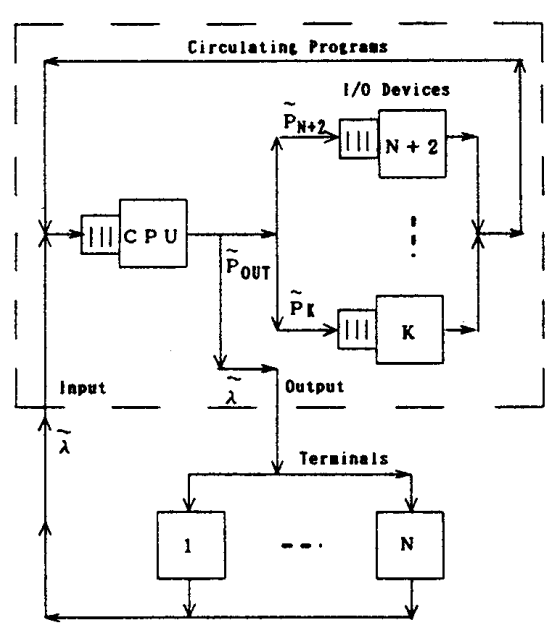

Fig.4 Closed BCMP computer system.

\section{Algorithm MVA}

Consider the closed BCMP system of Fig. 4. Suppose the mean think time $\widetilde{E}[t]=\widetilde{T}$ for each of the $N$ terminals. $\widetilde{W}_{k}[n]$ is the average total time that a customer spends at the $k$-th service center when there are $n$ customers in the system. $\widetilde{L_{k}}[n]$ is the average number of customers that find at $k$ service center when there are $n$ customers in the system. Each terminal is a Type 3 server. The CPU (device number $N+1$ ) is either a Type 1 or Type 2 server with service demand $\widetilde{D}=\widetilde{D}_{N+1}$ given. We are also given the service demands $\widetilde{D}_{k}, k=N+2$, $N+3, \ldots, K$ for the I/O devices. Then calculate the performance measures of the system as follows:

Step 1 [Initialize]

For $k=N+1, N+2, \ldots, K$, set

$L_{k}[0]=(0,0,0)$

Step 2 [Iterate]

For $n=1,2, \ldots, N$, calculate

$$
\begin{aligned}
& \widetilde{W}_{k}[n]=\widetilde{D}_{k}\left(1+\widetilde{L_{k}}[n-1]\right), \\
& k=N+1, N+2, \cdots, K, \\
& \widetilde{W}[n]=\sum_{k=N+1}^{K} \widetilde{W}_{k}[n], \\
& \forall \alpha \in[0,1] \text {, } \\
& \lambda[n](\alpha)=\left[\frac{n}{W[n]_{2}^{(\alpha)}+T_{2}^{(\alpha)}}, \frac{n}{W[n]_{1}^{(\alpha)}+T_{1}^{(\alpha)}}\right], \\
& L_{k}[n](\alpha)=\left[\lambda[n]_{2}^{(\alpha)} W_{k}[n]_{1}^{(\alpha)}\right. \text {, } \\
& \left.\lambda[n]_{1}^{(\alpha)} W_{k}[n]_{2}^{(\alpha)}\right], \\
& k=N+1, N+2, \cdots, K \text {. }
\end{aligned}
$$


Step 3 [Compute performance measures]

Set system throughput to

$\tilde{\lambda}=\tilde{\lambda}[N]$.

Set job response time (turnaround time) to

$\forall \alpha \in[0,1]$,

$W(\alpha)=\left[\frac{N}{\lambda_{2}^{(\alpha)}}-T_{1}^{(\alpha)}, \frac{N}{\lambda_{1}^{(\alpha)}}-T_{2}^{(\alpha)}\right]$.

[We have already calculated $\widetilde{W}=\widetilde{W}[N]$ in

Step 2, but we want to show the dependance of $\widetilde{W}$ on $\tilde{\lambda}, N$ and $\widetilde{T}$ explicitly.]

Set server utilizations to

$\tilde{\rho}_{k}=\tilde{\lambda} \widetilde{D}_{k}, \quad k=N+1, N+2, \cdots, K$.

We calculated $\widetilde{L_{k}}[N]$ and $\widetilde{W}_{k}[N]$ for each server in the last iteration of Step 2 .

\section{Numerical Examples}

Now, we show the numerical examples to demonstrate the proposed fuzzy open central system and fuzzy BCMP queueing network model.

\subsection{Example of Fuzzy Open Central Server Model}

We investigate a transaction processing computer system that can be modeled as an open central server model with one CPU and three disks as shown in Fig.3. We find that the TFN of average transaction arrival rate, $\tilde{\lambda}$ is $(0.18,0.2,0.21)$ transactions per second with an TFN of average CPU service requirement of $(2.8,3,3.2)$ seconds per transaction. The TFNs of average $\mathrm{I} / \mathrm{O}$ service requirements are $(0.9,1,1.1),(1.8,2,2.1)$, and $(3.9,4,4.1)$ seconds, respectively.

Let us step through Lavenberg's algorithm. In Step 1 , we set service demands for each device that is, $\widetilde{D}_{1}=(2.8,3,3.2), \widetilde{D}_{2}=(0.9,1,1.1)$, $\widetilde{D}_{3}=(1.8,2,2.1)$, and $\widetilde{D}_{4}=(3.9,4,4.1) \mathrm{sec}-$ onds.

In Step 2, we compute average number of transactions, utilizations and average response time for each device that is, $\widetilde{N}_{1}=(0.762,1.5$, $2.732), \widetilde{N}_{2}=(0.145,0.25,0.402), \widetilde{N}_{3}=(0.359$, $0.667,1.052)$, and $\widetilde{N}_{4}=(1.767,4,8.259)$ and $\tilde{\rho}_{k}, \widetilde{W}_{k}(k=1,2,3,4)$ as shown in the following Table 1 .
Table 1 Server utilization and response time

\begin{tabular}{c|c|c}
\hline $\begin{array}{c}\text { ser } \\
\text { ver } \\
k\end{array}$ & utilization & $\begin{array}{c}\text { response time } \\
\tilde{\rho}_{k}\end{array}$ \\
\hline 1 & $(0.504,0.600,0.672)$ & $(3.629 .7 .500 .15 .176)$ \\
2 & $(0.162,0.200,0.231)$ & $(0.690,1.250 .2 .225)$ \\
3 & $(0.324,0.400,0.441)$ & $(1.712 .3 .333 .5 .844)$ \\
4 & $(0.702,0.800,0.861)$ & $(8.413 .20 .000 .45 .833)$ \\
\hline
\end{tabular}

In Step 3, from Table 1 we calculate the average transaction response time

$$
\begin{aligned}
\widetilde{W} & =\widetilde{W}_{1}+\widetilde{W}_{2}+W_{3}+W_{4} \\
& =(14.444,32.083,69.128) \text { seconds, }
\end{aligned}
$$

and the average number of transactions being processed is

$$
\widetilde{N} \fallingdotseq(3.300,6.417,12.443) \text {. }
$$

The bottleneck is the third disk driver, so the TFN of maximum possible throughput, ${\tilde{\lambda_{\max }}}_{\text {is }}(0.244$, $0.25,0.256)$ transactions per second.

In this numerical example, we applied fuzzy set theory to the transaction processing computer system that can be modeled as the open central server model with one CPU and three disks. The proposed fuzzy approach can get the reasonable performance measures suitable for all cases ranging from the minimum value to the maximum value. Also, we can verify the reality and the flexibility because the results, i.e., the performance measures maintain the fuzziness of input information.

\subsection{Example of Fuzzy BCMP Queueing Network Model}

We have an interactive computer system consisting of 50 active terminals connected to a central computer system as shown in Fig. 4. We find that we can model the system by the queueing model described in Algorithm MVA with three I/O devices. We find that the average think time is $(14,15,17)$ seconds, the mean CPU service demand per interaction (job) is $(0.13,0.15,0.18)$ seconds, and the mean total service demand per interaction on the three $\mathrm{I} / \mathrm{O}$ devices is $(0.01,0.02$, $0.03),(0.03,0.04,0.05)$, and $(0.04,0.05$, $0.06)$ seconds, respectively.

Let us step through MVA algorithm.

In Step 1, we initialize to $\widetilde{L_{51}}[0]=\widetilde{L_{52}}[0]=\widetilde{L_{53}}$ 
Table 2 Calculations for Example 1

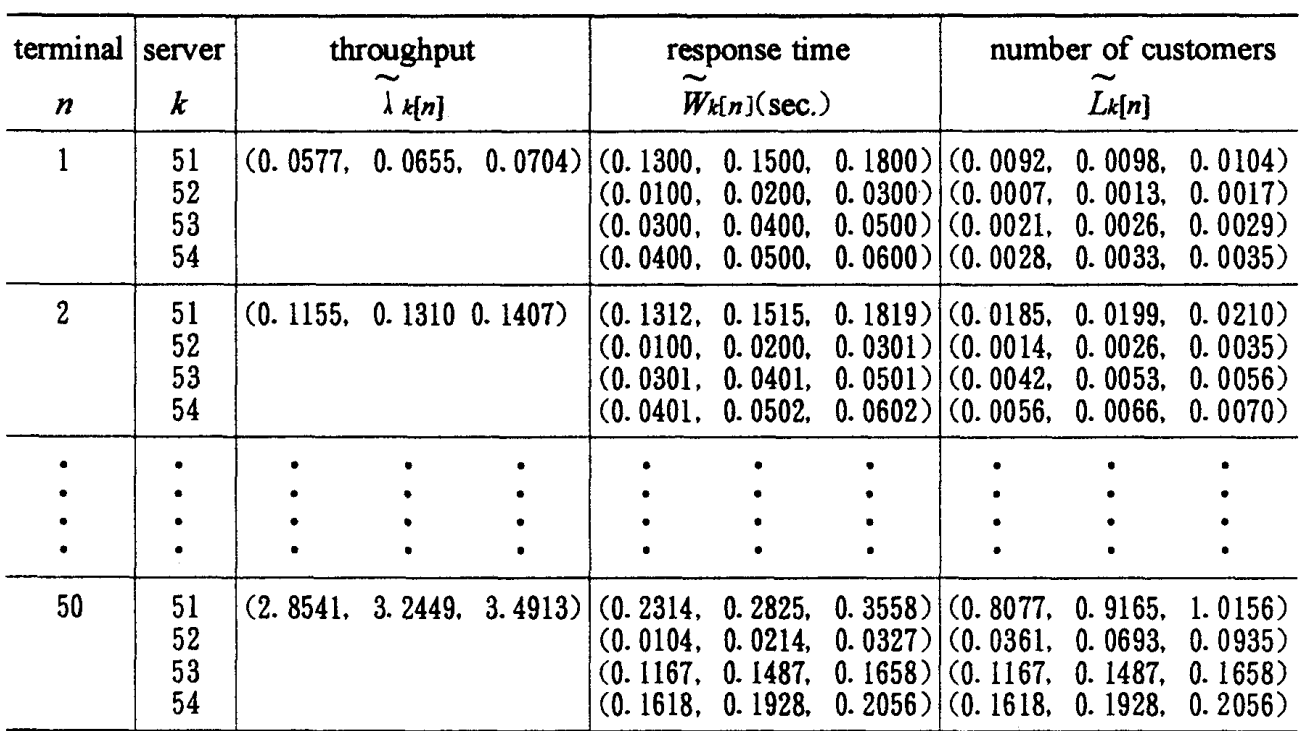

$[0]=\widetilde{L_{54}}[0]=(0,0,0)$.

In Step 2, we calculate average response time and average number of interaction for each device, a part of which are shown in Table 2 .

In Step 3, we find that system throughput $\tilde{\lambda}=$ $(2.8541,3.2448,3.4913)$ interaction per second, response time $\widetilde{W}=(0.3215,0.4090,0.5187)$ seconds, utilization of $\mathrm{CPU} \tilde{\rho}_{\mathrm{CPU}}=(0.3710,0.4867$, $0.6284)$, and the average number of interaction in the central computer system $\tilde{L}=(1.1223,1.3273$, 1.4805).

In this numerical example, we applied fuzzy set theory to the interactive computer system that can be modeled as the closed single class BCMP model with 50 active terminals and three disks. The practical merit of this approach is that there is no need to force designer to give a probability distribution. And fuzzy approach can get a reasonable solution suitable for all cases ranging from the pessimistic case to the optimistic case.

When the crisp data of the conventional BCMP queueing model are the modal values of the above input data, the performance measures of this model get the modal values of the above results. Therefore, we can verify the reality and the flexibility because the results i.e. the performance measures maintain the fuzziness of input information.

\section{Conclusion}

In this paper, a fuzzy $M / M / 1$ system that is applied the fuzzy Little's law was proposed. The performance measures for fuzzy open central server network model and fuzzy closed single class BCMP queueing network model were analyzed by Lavenberg's algorithm and MVA algorithm, respectively. Therefore we can get the more realistic performance measures when some data of queueing network models are ambiguous.

\section{References}

[1] H. M. Prade, An Outline of Fuzzy or Possibilistic Models for Queueing Systems, Fuzzy sets, P. P Wang and S. K Chang eds., Plenum Press(1980)

[2] J. J. Buckley, Elementary Queueing Theory Based on Possibility Theory, Fuzzy Sets and Systems, Vol.37, pp.43-52 (1990)

[3] D. Dubois and H. Prade, Fuzzy Sets and Systems : Theory and Applications, Plenum Press (1980)

[4] D. S. Negi and E. S. Lee, Analysis and Simulation of Fuzzy Queues, Fuzzy Sets and Systems, Vol.46, pp.321-330 (1992)

[5] R. J. Li and E. S. Lee, Analysis of Fuzzy Queues, Computers and Mathematics with Applications, Vol. 17, pp.1143-1147 (1989)

[6] A. O. Allen, Probability, Statistics, and Queueing Theory with Computer Science Applications, 2nd ed., Academic Press (1990)

[7] H. J. Zimmermann, Fuzzy Set Theory and Its Applications, 2nd ed., Kluwer Academic Publishers (1991)

[8] D. P. Bertsekas, Data Networks, 2nd ed., Prentice-Hall Inc. (1992)

[9] R. W. Wolff, Stochastic Modeling and the Theory of Queues, Prentice-Hall Inc.(1989) 
[10]G. Yamazaki, N. Kobayashi, H. Takagi, R.W. Wolff, Performance Analysis of a Slotted Ring LAN by a single-buffer Model, Trans. IEICE, Vol.J76-B-I, No.4, pp.340-348(1993)

[11]F. Baskett, K.M. Chandy, R.R. Muntz, and F. G. Palacios, Open, Closed, and Mixed Networks of Queues with Different Class of Customer, J.ACM, Vol.22, No.3, pp.248-260 (1975)

[12]S. S. Lavenberg, ed. : Computer Performance Modelling Handbook, Academic Press(1983)

[13]E. Sanchez, Solution of Fuzzy Equations with Extended Operation, Fuzzy Sets and Systems, Vol. 12, pp.237-248(1984)

[14]J. J. Buckley and Y. Qu : Solving Linear and Quadratic Fuzzy Equations, Fuzzy Sets and Systems, Vol.38, pp.43-59(1990)

[15]J. B. Jo, Y. Tsujimura, M. Gen and G. Yamazaki: Performance Evaluation of a Fuzzy Queueing Network, Proc. of Fifth IFSA World Cong., Seoul, Korea, pp.580-583 (1993)

[16]J. B. Jo, Y. Tsujimura, M. Gen and G. Yamazaki, A Delay Model of Queueing Network System Based on Fuzzy Sets Theory, Proc. of 15th Conf. on Comp. \& Ind. Engg., Vol. 25, pp.143-146(1993)

[17]J. B. Jo, Y. Tsujimura, M. Gen and G. Yamazaki, A Network Model Based on Fuzzy Queueing System, Third IEEE Int. Conf. on Fuzzy Systems, U. S.A., pp.1951-1956(1994)

[18] J. B. Jo, Y. Tsujimura, M. Gen and G. Yamazaki, Failure Analysis of Computer System Based on Fuzzy Queueing Theory, Int. J. of Comp. \& Ind. Engg., Vol.27, Nos.1-4, pp.425-428(1994)

[19]J. B. Jo, Y. Tsujimura, M. Gen and G. Yamazaki, Performance Evaluation of Computer System with Failure Based on Fuzzy Set Theory, J. of the Operations Research Society of Japan, Vol.38, No. 4 (in press), (1995)
[20] J. B. Jo, J. K. Lee, J. U. Lee, M. Gen and G. Yamazaki, A Network Model Based on Fuzzy Queueing System, Korea Inst. of Telematics and Electronics (KITE) J. of Electro. Engg., Vol.6, pp. 50-55 (1955)

[21]R. E. Stanford, The Set of Limiting Distributions for a Markov Chain with Fuzzy Transition Probabilities, Fuzzy Sets and Systems, Vol.7, pp.7178(1982)

[22] Y. Yoshida, Markov Chain with a Transition Possibility Measure and Fuzzy Dynamic Programming, Fuzzy Sets and Systems, Vol.66, pp.39-57(1994)

[23]A. Kaufmann and M. M. Gupta, Fuzzy Mathematical Models in Engineering and Management Science, Van Nostrand Reinhold (1988)

[24]W. Pedrycz, Fuzzy Modeling: Methodology, Algorithms and Practice, In J. M. Zurade, P. J. Marks II, and C. J. Robinson, editors, Computational Intelligence: Imitating Life, section 2.3, IEEE Press, New York (1994)

[25]K. N. Otto and E. K. Antonsson, Modeling Imprecision in Product Design, FUZZ-IEEE'94, pp. 346-359 (1994)

[26]G. J. Klir and T. A. Folger, Fuzzy Sets, Uncertainty, and Information, Prentice-Hall (1988)

[27] H. Tanaka, L. T. Fan, F. S. Lai and K. Toguchi, Fault-Tree Analysis by Fuzzy Probability, IEEE Trans. on Reliability, Vol.R-32, No.5, pp.453457 (1983)

$\begin{array}{llr}\text { (1995年2月 } 16 \text { 日 } & \text { 受 } & \text { 付) } \\ \text { (1995年7月31日 } & \text { 再受 } & \text { 付) }\end{array}$

[間い命わせ先]

于326 足利市大前町268

足利工業大学 経営 1 学科

边村 泰寞

TEL：0284-62-0605(队) 378

FAX : 0284-64-1071

\section{著者紹 介}

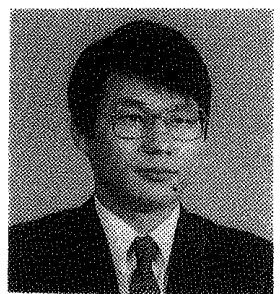

曹廷輻(しょょ゙んはく)

韓国、東西科大学校コンピュー夕学科 1986年 韓国、慶南大学校に招いて電気 土学の分野で士学修士を取得. 1996年 東 京都立科学技術大学大学院1: “研究科 博士課程修了. 現在、韓国、東西「科大学: 校コンピュータ学科助教授、現在に至る。 工学博士。ファジィ待ち行列理淪とそれ によるコンピュータ・システムの性能評 洒に関子る研究に従事。 月本ファジィ学: 会会員。

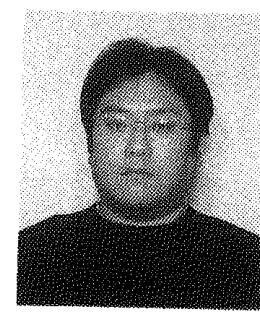

辻村 泰寬(のしむ斿やするろ)

足利 L業大学: 経学 I学科

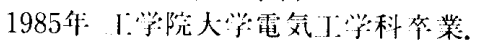

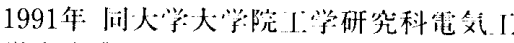
学尃攻博士課程修了。1991年处利「業大 学経営:工学科助手、1992年 间講師、1995 年同助教授、現在に主る。1993年～1995 年起和工業大学情報科学センター兼務。

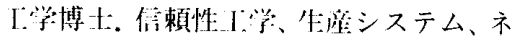
ットワーク洲技術、およびそれらへの ファジィ理論、ニューラルネット、遺伀的 アルゴリズムの灾朋に関する研究に従事。 IIE、電気学全、川本ファジィ学丟、情報

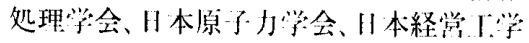
会、日本信賴性:兴会等会戈。 


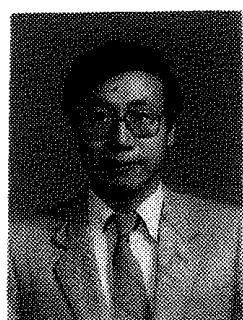

玄光男(げんみつお)

足利 $\mathrm{T}$. 業大学: 経営 $\mathrm{L}$ 学:科

昭和44年．学院大学: 一工。電子卒業, 昭和 49 年 闹大大学院博士:課程修了。间年 足利工業大学・ $・$. 経営 $\mathrm{T}$ 学講師, 昭和 55 年 问助教授，昭和62年. 闹教授，現在に 至る。平成元年 $~ 7$ 年 足利工大・情報科学 (前AITnet) 七ンター長. 昭和56年 $~ 57$ 年米国Univ, of Nebraska-Lincoln密真 助教授。厂学博士。 ファジィシステムI 学、ファジィ多月的計酶法, 遺伀的アルゴ リズムの応拄等の研究開発に従事。著書 「線形計画・U標計画プログラム」(昭和 59年 電気書院)，“Genetic Algorithms and Engineering Design", John Wiley \& Sons, 1996なよ゙. 日本ファジィ学会, 日本オペレーションズ・リサー千学:会, 電 于情報通信学会, 川本経営1学丟, 情報処 理学全，IEEE，IIE等备全是。

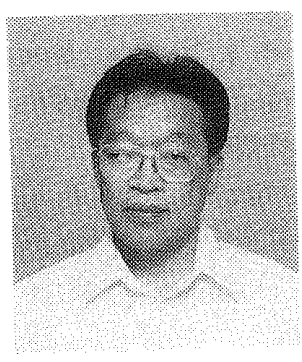

山崎 源治(やまざきげんじ)

東京都立科学技術大学管理 1 学科

1975年 「学院大学大学院厂学研究科

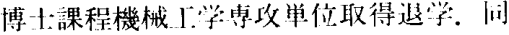
年4月工学院大学生産機械厂学科助手. 1986年. 東京都立科学技術大学管理 1 学: 科助教授、現在に至る。1学博士1: 各員教 授: University of California, Berkeley(1993年)、条員研究員：The Aus tralian National University (1993年)、 INRIA (Institut National de Recherche en Informatique et en Automatique, フランス)(1994年)、CWI(Centrum voor Wiskunde en Informatica, オ ンダ) (1994年)。確泮そデルとその忍月月

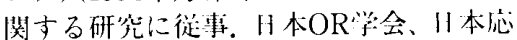
用数理学会、日本機械学:会、日本経賞「学: 会等の会員.

\section{Performance Evaluation of Network Models based on Fuzzy Queueing System}

by

\section{Jung Bok JO, Yasuhiro TSUJIMURA, Mitsuo GEN and Genji YAMAZAKI}

\section{Abstract :}

The purpose of this paper is to combine the ability of fuzzy set to represent more realistic situations with the well-established traditional queueing network model problem. We are forced to employ subjective probabilities when there is no information about a model or some parameters of a model are vague. The information and data are very fuzzy, because they are frequently very little, and may be sometimes obtained from experts subjectively. We propose a fuzzy $\mathrm{M} / \mathrm{M} / 1$ queueing system which is derived by fuzzification of ordinary $\mathrm{M} / \mathrm{M} / 1$ queueing system. We also apply fuzzy set theory to the open central server network model with the fuzzy queues and the closed single class BCMP network model in which each node consists of fuzzy queue. Thus, we represent the characteristic and performance of the open central server network model and the closed single class BCMP network model based on the proposed fuzzy queueing system.

Keywords : Fuzzy Set Theory, M/M/1 Queueing Model, Markov Chains, Open Central Server Model, Closed Single Class BCMP Model

\section{Contact Address : Yasuhiro TSUJIMURA}

Dept. of Industrial and Systems Engineering, Ashikaga Institute of Technology

268 Ohmae-cho, Ashikaga, 326 Japan

TEL : 0284-62-0605(EX.378)

FAX : 0284-64-1071

\section{ファジィ待ち行列システムによるネットワークモデルの性能評価}

コンピュータシステムの待ち行列モデルによる性能評価では, 従来, 確摔過程に基づいて, 到着時間やサー ビス時間などを確定値として取り扱ってきた。しかし，現实には，これらの值を確定值で表現するよりはむし ろ「「だいたいこれぐらい」というようなあいまいな值で表現するほうが適切な場合が多い.

本論文ではこのあいまいさを表現するた如に三解型ファジィ数を導入する。まず，ファジィ方程式の解法を 示し, 次いで従来の $\mathrm{M} / \mathrm{M} / 1$ 待ち行列をファジィ化して, コンピュータシステムの待ち行列ネットワークモデ ル，すなわちここでは解放型セントラル・サーバ・モデルと閉鎖型単一クラスBCMPモデルに適肘する。これ により,促来のコンピュータシステムの待ち行列モデルより実際的で柔軟なコンピュータシステムモデルの性 能評価を行うことが可能になる。.さらに，数值例を羘いて提案する手法の有効性を確認する。

キーワード：ファジイ理論， $M / M / 1$ 待ち行列モデル，マルコフ連鎖，解放型セントラル・サーバ・モデル，閉 鎖型BCMPネットワークモデル 